\title{
Structure of variation among morphological and physiological traits in three pearl millet composites
}

\author{
H.F. Rattunde ${ }^{1}$, J.R. Witcombe ${ }^{2}$ and K.J. Frey ${ }^{3}$ \\ ${ }^{1}$ Institute of Plant Breeding, Seed Science, and Population Genetics, Univ. of Hohenheim, D-7000 Stuttgart \\ 70, F.R.G.; ${ }^{2}$ ICRISAT, Patancheru, A.P., 502 324, India; ${ }^{3}$ Department of Agronomy, Iowa. State Univ., \\ Ames, IA 50011, USA
}

Received 14 June 1988; acceptè̀ in revised form 24 August 1988

Key words: Pennisetum glaucum, pearl millet, factor analysis, morphological traits, physiological traits, grain yield, yield determinants, pleiotropy

\section{Summary}

The plant breeder's task of improving and stabilizing many plant traits simultaneously is complicated by interrelationships that occur among the traits. Factor analyses were conducted on three phenotypically diverse pearl millet [Pennisetum glaucum (L.) R. Br.] composites to describe the structure of relationships among yield, morphological, and physiological traits. Approximately $1000 \mathrm{~S}_{0}$ spaced-plants from each composite were evaluated for 20 traits, and random samples of $289 \mathrm{~S}_{1}$ progenies from each composite were evaluated for 18 of these traits. Factors extracted in $S_{0}$ and $S_{1}$ populations identified unique sets of traits that were interrelated along axes of (a) biological yield, (b) panicle size, (c) dry matter partitioning and (d) compensation between number and size of seeds. Several plant traits had large loading coefficients on the 'Biological Yield' and also, but with opposite signs, on the 'Dry Matter Partitioning' factor. The traits having large loadings on these two factors differed between space-planted and normal-density stands, showing that environmental conditions contributed to the associations observed among traits. Correlations of $S_{1}$ with parental $S_{0}$ factor scores for the 'Biological Yield', 'Panicle Size' and 'Seed Paramters' factors produced significant correlation coefficients, indicating that these trait complexes had a genetic basis. The implications of these results for millet breeding are discussed.

\section{Introduction}

Pearl millet [Pennisetum glaucum (L.) R.Br.] consists of a large number of genetically variable races (Brunken et al., 1977). The variability among races has been sampled by intermating lines from diverse geographic origins to form several broad-based breeding populations (Burton, 1959; Khadr, 1977). Success in breeding such populations is influenced considerably by the presence of genetic associations among traits. For instance, the array of possible recombinant types is very limited if several traits are inherited pleiotropically (Stebbins, 1950). Favorable genetic associations can be exploited in germplasm development via indirect selection, whereas unfavorable associations require special techniques to minimize undesirable correlated responses to selection. 
Complexes of related traits were identified by Bramel-Cox et al. (1987), who used principal components analysis to summarize data from pearl millet populations derived from matings of adapted with wild, weedy or landrace accessions. Interrelationships among plant height, stem diameter, leaf length, and flowering date were described by the first principal component. This axis of variation was oriented toward the exotic plant type at one extreme and toward the adapted type at the other. In another multivariate study (Marchais \& Tostain, 1985), associations among floral and seed characteristics were exhibited in progenies from matings between wild and cultivated pearl millet lines.

The objective of our study was to determine what relationships exist among morphological, physiological, and yield traits of three genetically broad-based pearl millet composites which are undergoing population improvement. Multivariate methods were used 1 ) to identify major complexes of related traits in each composite, 2) to determine whether trait complexes are similar across composites and environments, and 3) to assess whether multitrait associations are genetic in origin.

\section{Materials and methods}

Genetic materials. The three pearl millet composites, Dwarf Composite $\left(\mathrm{D}_{2} \mathrm{C}\right)$, New Early Composite (EC), and New Elite Composite (NELC), were chosen for this study as they represented a broad range of height and maturity (Table 1). The EC and NELC composites were created by intermating 117 and 47 lines, respectively, of African and Indian origin, whereas the $\mathrm{D}_{2} \mathrm{C}$ composite was created by intercrossing 23 African lines. After a single generation of random mating, three to five cycles of recurrent selection for grain yield and disease resistance were conducted in each composite. $\mathrm{S}_{0}$ seed

Table 1. Means and ranges of eight traits measured on $\mathrm{S}_{0}$ plants and $\mathrm{S}_{1}$ progenies from the $\mathrm{D}_{2} \mathrm{C}, \mathrm{EC}, \mathrm{NELC}$ pearl millet composites; the recurrent selection cycle from which $S_{0}$ plants were derived; and the numbers of entries analyzed in $S_{0}$ and $S_{1}$ populations

\begin{tabular}{|c|c|c|c|c|c|c|c|c|c|c|}
\hline Composite & Cycle & $\begin{array}{l}\text { Number of } \\
\text { entries }\end{array}$ & $\begin{array}{l}\text { Tillers per } \\
\text { plant }\end{array}$ & $\begin{array}{l}\text { Seeds per } \\
\text { panicle } \\
(\times 100)\end{array}$ & $\begin{array}{l}\text { 100-seed } \\
\text { weight }(\mathrm{g})\end{array}$ & $\begin{array}{l}\text { Growth } \\
\text { index } \\
\left(\mathrm{g} \mathrm{day}^{-1}\right. \\
\text { plt }^{-1} \text { ) }\end{array}$ & $\begin{array}{l}\text { Days to } \\
\text { flower } \\
\text { (DAE) }\end{array}$ & $\begin{array}{l}\text { Height } \\
(\mathrm{cm})\end{array}$ & $\begin{array}{l}\text { Harvest } \\
\text { index }(\%)\end{array}$ & $\begin{array}{l}\text { Grain plant }{ }^{-1} \\
\text { (g) }\end{array}$ \\
\hline \multicolumn{11}{|c|}{$S_{0}$ populations } \\
\hline $\mathrm{D}_{2} \mathrm{C}$ & 3 & 993 & $\begin{array}{l}7.0 \\
2-17\end{array}$ & $\begin{array}{l}22.3 \\
5.5-52.7\end{array}$ & $\begin{array}{l}1.08 \\
0.63-1.48\end{array}$ & $\begin{array}{l}1.70 \\
0.39-4.72\end{array}$ & $\begin{array}{l}47.0 \\
34-60\end{array}$ & $\begin{array}{l}107 \\
73-159\end{array}$ & $\begin{array}{l}46.2 \\
27-60\end{array}$ & $\begin{array}{l}116 \\
38-415\end{array}$ \\
\hline $\mathrm{EC}$ & 5 & 1017 & $\begin{array}{l}7.8 \\
3-18\end{array}$ & $\begin{array}{l}24.6 \\
5.5-72.9\end{array}$ & $\begin{array}{l}1.14 \\
0.55-1.65\end{array}$ & $\begin{array}{l}2.61 \\
0.45-7.02\end{array}$ & $\begin{array}{l}44.8 \\
35-58\end{array}$ & $\begin{array}{l}156 \\
102-212\end{array}$ & $\begin{array}{l}44.7 \\
25-59\end{array}$ & $\begin{array}{l}148 \\
37-365\end{array}$ \\
\hline NELC-I & 4 & 1076 & $\begin{array}{l}5.9 \\
2-14\end{array}$ & $\begin{array}{l}32.1 \\
8.3-66.9\end{array}$ & $\begin{array}{l}1.17 \\
0.65-1.65\end{array}$ & $\begin{array}{l}2.46 \\
0.48-5.95\end{array}$ & $\begin{array}{l}53.0 \\
38-66\end{array}$ & $\begin{array}{l}165 \\
94-221\end{array}$ & $\begin{array}{l}41.9 \\
25-54\end{array}$ & $\begin{array}{l}143 \\
36-361\end{array}$ \\
\hline NELC-II & 4 & 1133 & $\begin{array}{l}5.6 \\
1-13\end{array}$ & $\begin{array}{l}40.2 \\
8.5-93.5\end{array}$ & $\begin{array}{l}1.11 \\
0.48-1.80\end{array}$ & $\begin{array}{l}3.51 \\
0.65-8.00\end{array}$ & $\begin{array}{l}48.4 \\
42-57\end{array}$ & $\begin{array}{l}209 \\
125-275\end{array}$ & $\begin{array}{l}43.5 \\
25-56\end{array}$ & $\begin{array}{l}199 \\
24-412\end{array}$ \\
\hline \multicolumn{11}{|c|}{$S_{1}$ populations } \\
\hline $\mathrm{D}_{2} \mathrm{C}$ & & 289 & $\begin{array}{l}1.8^{\mathrm{a}} \\
1.1-3.3\end{array}$ & $\begin{array}{l}15.8 \\
5.6-28.8\end{array}$ & $\begin{array}{l}0.71 \\
0.41-0.94\end{array}$ & $\begin{array}{l}0.37^{\mathfrak{b}} \\
0.14-0.68\end{array}$ & $\begin{array}{l}50.3 \\
40-65\end{array}$ & $\begin{array}{l}126 \\
94-166\end{array}$ & $\begin{array}{l}38.0 \\
22-50\end{array}$ & $\begin{array}{l}19^{c} \\
8-33\end{array}$ \\
\hline $\mathrm{EC}$ & & 289 & $\begin{array}{l}2.1 \\
1.1-3.2\end{array}$ & $\begin{array}{l}15.4 \\
5.6-28.9\end{array}$ & $\begin{array}{l}0.70 \\
0.45-1.05\end{array}$ & $\begin{array}{l}0.51 \\
0.26-1.02\end{array}$ & $\begin{array}{l}45.1 \\
39-54\end{array}$ & $\begin{array}{l}177 \\
131-218\end{array}$ & $\begin{array}{l}37.1 \\
16-47\end{array}$ & $\begin{array}{l}21 \\
10-34\end{array}$ \\
\hline NELC-I & & 289 & $\begin{array}{l}1.6 \\
0.8-2.9\end{array}$ & $\begin{array}{l}20.4 \\
9.3-38.9\end{array}$ & $\begin{array}{l}0.74 \\
0.47-1.04\end{array}$ & $\begin{array}{l}0.53 \\
0.26-0.83\end{array}$ & $\begin{array}{l}50.8 \\
44-64\end{array}$ & $\begin{array}{l}193 \\
119-245\end{array}$ & $\begin{array}{l}36.6 \\
23-46\end{array}$ & $\begin{array}{l}23 \\
11-36\end{array}$ \\
\hline NELC-II & & 289 & $\begin{array}{l}1.4 \\
0.8-2.3\end{array}$ & $\begin{array}{l}18.0 \\
5.9-32.5\end{array}$ & $\begin{array}{l}0.73 \\
0.42-1.11\end{array}$ & $\begin{array}{l}0.56 \\
0.32-0.83\end{array}$ & $\begin{array}{l}58.8 \\
49-68\end{array}$ & $\begin{array}{l}210 \\
157-258\end{array}$ & $\begin{array}{l}26.7 \\
13-38\end{array}$ & $\begin{array}{l}16 \\
5-29\end{array}$ \\
\hline
\end{tabular}

${ }^{\mathrm{a}}$ Number of panicles $\mathrm{m}^{-2}$ divided by 13.3 (expected number of plants $\mathrm{m}^{-2}$ ).

${ }^{\mathrm{b}}$ Grams day ${ }^{-1} \mathrm{~m}^{-2}$ divided by 13.3 (expected number of plants $\mathrm{m}^{-2}$ ).

${ }^{\mathrm{c}}$ Grams $\mathrm{m}^{-2}$ divided by 13.3 (expected number of plants $\mathrm{m}^{-2}$ ). 
used to initiate this study was produced by open pollination among the 50 to 60 lines selected in the most recently completed cycle of recurrent selection for each composite.

Field experiments. $\mathrm{S}_{0}$ seeds of each composite were sown in 1440 hills during the 1985 dry season (January-April) at the International Crops Research Institute for the Semi-Arid Tropics (ICRISAT) near Hyderabad, India. Sowing dates were 11 January for $\mathrm{D}_{2} \mathrm{C}$ and NELC and 14 January for EC. $\$_{1}$ seed was produced by selfing the second and third tillers of each plant, and an unselected set of $289 \mathrm{~S}_{1}$ progenies from each composite was sown on 21 June in the 1985 wet season (June-September). On the same date, a second sample of 1440 hills of $S_{0}$ seeds from NELC was sown. These $S_{0}$ plants were selfed, and a random set of 289 of the resulting $\mathrm{S}_{1}$ progenies were sown on 18 June in the 1986 wet season. The $S_{0}$ plants and $S_{1}$ progenies from the second sampling of NELC will be labeled NELC-II, and those from the first sampling will be labeled NELC-I.

$\mathrm{S}_{0}$ seeds were sown in hills spaced $75 \mathrm{~cm}$ apart on ridges formed at $75-\mathrm{cm}$ intervals. Three to five seeds were sown per hill, and 10 days after emergence, the seedlings were thinned to one per hill. Seedlings were transplanted into missing hills. $S_{1}$ progenies from a composite were evaluated in a $17 \times 17$ triple lattice experiment. A plot consisted of two rows each $2 \mathrm{~m}$ long sown on ridges spaced at $75-\mathrm{cm}$ intervals. Plants within rows were thinned to a 10 -cm spacing.

$\mathrm{S}_{0}$ and $\mathrm{S}_{1}$ experiments were conducted on Alfisol soils at the ICRISAT Center, Patancheru, India, at $17^{\circ} \mathrm{N}$ latitude. Rainfall was $51 \mathrm{~mm}$ during the 1985 dry season, $311 \mathrm{~mm}$ during the 1985 wet season, and $460 \mathrm{~mm}$ during the 1986 wet season. Furrow irrigation was used throughout the dry season and twice at the end of the 1985 wet season. Average weekly maximum temperatures increased throughout the dry season from 29 to $40^{\circ} \mathrm{C}$, whereas they fluctuated between 28 to $34^{\circ} \mathrm{C}$ during the 1985 and 1986 wet seasons. Plants were sprayed with the insecticides Endosulfan 35E and Carbaryl 50 WP during grain filling in the wet seasons to control leaf-feeding insects, such as Mythimna separata.
Each experiment received broadcast applications of $40 \mathrm{~kg} / \mathrm{haN}$ and $17 \mathrm{~kg} / \mathrm{haP}$ before planting and $40 \mathrm{~kg} / \mathrm{ha} \mathrm{N}$ via topdressing of urea at 15 to 22 days after seedling emergence.

Traits. Traits measured on $\mathrm{S}_{0}$ plants and $\mathrm{S}_{1}$ progenies, their abbreviations, and methods of measurement are presented in Table 2 . All traits were measured on all three replications of each $\mathrm{S}_{1}$ experiment except that (a) only two replications were measured for leaf width (LfWi) and plant height in all experiments and panicle length ( $\mathrm{PaLe}$ ) and panicle girth (PaGi) in NELC-II and (b) LfWi was not measured in the $\mathrm{D}_{2} \mathrm{CS}_{1}$ experiment. Growth index (GI) was calculated by using the procedure presented by Bramel-Cox et al. (1984). All traits were measured at harvest except for days to flowering $(\mathrm{DaFl})$, which was recorded at flowering, and height, $\mathrm{LfWi}$, and tiller number on $\mathrm{S}_{0}$ plants and height, LfWi, PaLe, PaGi, and panicle compactness on $S_{1}$ progenies, all of which were measured 2 weeks before harvest. All dry weights were recorded after plant materials were dried for $16 \mathrm{hr}$ at $65^{\circ} \mathrm{C}$, except for $\mathrm{S}_{0}$ plant panicles, which were dried at $35^{\circ} \mathrm{C}$ for $24 \mathrm{hr}$.

Analysis of $\mathrm{S}_{0}$ populations was conducted on data from plants that produced at least $6 \mathrm{~g}$ of $\mathrm{S}_{1}$ seed; had Threshing percent (Th\%) within the range of $60-85 \%$; Harvest index $(\mathrm{HI})$ within the ranges of $25-54 \%$ for NELC, $25-59 \%$ for EC, and $27-60 \%$ for $\mathrm{D}_{2} \mathrm{C}$; and $\mathrm{DaFl}$ within the ranges of 35-58 days for EC, 34-60 for $\mathrm{D}_{2} \mathrm{C}, 38-66$ for NELC-I, and 42-57 for NELC-II. Data from transplants were not included in the analyses.

Statistical analysis. Principal component analysis and factor analysis provide concise descriptions of large correlation matrices by generating a few random variables of hypothetical and unobservable nature that represent major multitrait axes of variation. Principal component analysis was used in the preliminary data summaries to determine the number of variables $(m)$ required to describe a major portion of the variation in each population. Subsequently, the matrix of correlations among traits $\left(\mathrm{x}_{1}, \mathrm{x}_{2}, \ldots, \mathrm{x}_{\mathrm{p}}\right)$ was described by $\mathrm{m}$ factors in each population according to the factor analysis model (Karson, 1982): 


$$
\begin{aligned}
& \mathrm{X}_{\mathrm{i}}=\mathrm{U}_{\mathrm{i}}+\lambda_{\mathrm{i} 1} \mathrm{Y}_{1}+\lambda_{\mathrm{i} 2} \mathrm{Y}_{2}+\lambda_{\mathrm{im}} \mathrm{Y}_{\mathrm{m}}+\mathrm{Z}_{\mathrm{i}} \\
& (\mathrm{i}=1,2, \ldots \mathrm{p}) \\
& (\mathrm{j}=1,2, \ldots \mathrm{m})
\end{aligned}
$$

where $U_{i}$ is the expectation of trait $X_{i} ; Y_{1}, Y_{2}, \ldots$ $Y_{m}$, are the factors assumed to be common in linearly generating traits $\mathrm{X}_{1}$ through $\mathrm{X}_{\mathrm{p}} ; \lambda_{\mathrm{ij}}$ is the loading coefficient of the ith original trait on the common factor $Y_{j}$; and $Z_{i}$ is the specific factor pertaining to a single trait $X_{\mathrm{i}}$. By noting those traits with large loading coefficients on a given common factor one can identify the complex of related traits described by that factor. The number of trait complexes identified in each population corresponded, therefore, with the $\mathrm{m}$ factors extracted in a given population. To facilitate biological interpretation of each factor, the factors were reoriented by using a promax rotation, with varimax prerotation, so that resulting loading coefficients approached plus or minus

\begin{tabular}{|c|c|c|c|}
\hline \multirow[t]{2}{*}{ Trait } & \multirow[t]{2}{*}{ Abbreviations } & \multicolumn{2}{|l|}{ Method of measurement or calculation } \\
\hline & & $\mathrm{S}_{0}$ plants & $S_{i}$ plots \\
\hline Days to flowering & $\mathrm{DaFl}$ & $\begin{array}{l}\text { Days after emergence when primary } \\
\text { panicle had emerged stigmas (DAE) }\end{array}$ & $\begin{array}{l}\text { Days after emergence when } 50 \% \text { of } \\
\text { panicles in plot had emergence stigmas } \\
\text { (DAE) }\end{array}$ \\
\hline Tiller synchrony & TSyn & $\begin{array}{l}\text { DaFl - days after emergence when third } \\
\text { tiller had emerged stigmas (days) }\end{array}$ & - \\
\hline Growth index & GI & $\mathrm{SYd} /(\mathrm{DaFl}+10)\left(\mathrm{g} / 0.56 \mathrm{~m}^{2} /\right.$ day $)$ & $\mathrm{SYd} /(\mathrm{DaFl}+10)\left(\mathrm{g} / 0.75 \mathrm{~m}^{2} / \mathrm{day}\right)$ \\
\hline Primary panicle grain yield & PPGYd. & $\begin{array}{l}\text { Mass of seed from panicle of primary } \\
\text { tiller }(\mathrm{g})\end{array}$ & - \\
\hline Threshing percent & Th\% & $\begin{array}{l}100 * \text { PPGYd/mass of primary-tiller } \\
\text { panicle }(\%)\end{array}$ & $100 *$ GYd/PYd (\%) \\
\hline Panicle yield & PYd & $\begin{array}{l}\text { Total mass of all mature panicles ( } \mathrm{g} / \\
\text { plant) }\end{array}$ & $\begin{array}{l}\text { Mass of panicles from } 1.5 \mathrm{~m} \text { length of two } \\
\text { rows }\left(\mathrm{g} / 2.25 \mathrm{~m}^{2}\right)\end{array}$ \\
\hline Grain yield & GYd & Th\%/100* PYd (g/plant) & $\begin{array}{l}\text { Mass of grain from } 1.5 \mathrm{~m} \text { length of two } \\
\text { rows }\left(\mathrm{g} / 2.25 \mathrm{~m}^{2}\right)\end{array}$ \\
\hline Straw yield & SYd & $\begin{array}{l}\text { Vegetative dry matter at maturity (g/ } \\
\text { plant) }\end{array}$ & $\begin{array}{l}\text { Vegetative dry matter at maturity from } \\
0.5 \mathrm{~m} \text { length of two rows }\left(\mathrm{g} / 0.75 \mathrm{~m}^{2}\right)\end{array}$ \\
\hline Biomass & Biomass & PYd + SYd (g/plant) & $\mathrm{PYd}+\left(3^{*} \mathrm{SYd}\right)\left(\mathrm{g} / 2.25 \mathrm{~m}^{2}\right)$ \\
\hline Harvest index & $\mathrm{HI}$ & $100 * \mathrm{GYd} / \mathrm{BM}(\%)$ & $100 * \mathrm{GYd} / \mathrm{BM}(\%)$ \\
\hline Reproductive ratio & $\mathrm{RR}$ & $100 * \mathrm{PYd} / \mathrm{BM}(\%)$ & $100 * \mathrm{PYd} / \mathrm{BM}(\%)$ \\
\hline Height & Height & $\mathrm{cm}$ from soil to tip of primary panicle & $\begin{array}{l}\mathrm{cm} \text { from soil to above } 50 \% \text { of primary- } \\
\text { panicle tips in the plot }\end{array}$ \\
\hline Leaf width & LfWi & $\begin{array}{l}\text { Blade with } 10 \mathrm{~cm} \text { from the ligule on } \\
\text { penultimate leaf of primary tiller }(\mathrm{cm})\end{array}$ & $\begin{array}{l}\text { Mean blade width } 10 \mathrm{~cm} \text { from the ligule } \\
\text { on penultimate leaves of four primary } \\
\text { tillers }(\mathrm{cm})\end{array}$ \\
\hline Tiller number & $\mathrm{T} \#$ & $\begin{array}{l}\text { Number of tillers with physiologically } \\
\text { mature seed at harvest }\end{array}$ & $\begin{array}{l}\text { Numbers of panicles harvested from } \\
1.5 \mathrm{~m} \text { length of two rows }\end{array}$ \\
\hline Seed weight & $200 S W$ & $\mathrm{~g} / 200$ seeds & $g / 200$ seeds \\
\hline Seed number per panicle & $\mathrm{S \# /Pa}$ & PPGYd/ (200SW/2) (×100/panicle $)$ & $(\mathrm{GYd} / \mathrm{T} \#) /(200 \mathrm{SW} / 2)(\times 100 /$ panicle $)$ \\
\hline Panicle length & PaLe & Length of primary panicle $(\mathrm{cm})$ & $\begin{array}{l}\text { Mean length of five primary panicles } \\
(\mathrm{cm})\end{array}$ \\
\hline Panicle girth & $\mathrm{PaGi}$ & Girth of primary panicle $(\mathrm{cm})$ & Mean girth of five primary panicles $(\mathrm{cm})$ \\
\hline Panicle surface area & PaSuAr & $\mathrm{PaLe}^{*} \mathrm{PaGi}\left(\mathrm{cm}^{2}\right)$ & $\mathrm{PaLe}^{*} \mathrm{PaGi}\left(\mathrm{cm}^{2}\right)$ \\
\hline Compactness score & $\operatorname{CoSc}$ & $\begin{array}{l}\text { Subjective score ( } 1 \text { to } 9 \text { ) of compactness } \\
\text { of the primary panicle }\end{array}$ & $\begin{array}{l}\text { Subjective score ( } 1 \text { to } 9 \text { ) of compactness } \\
\text { of five primary panicles }\end{array}$ \\
\hline Chaff & Chaff & PYd - GYd (g/plant) & PYd - GYd (g/2.25 m²) \\
\hline
\end{tabular}
1.0 for strongly associated traits and 0.0 for unasso-

Table 2. Traits measured on $\mathrm{S}_{0}$ plants and $\mathrm{S}_{1}$ progenies of pearl millet, their abbreviations, and methods of measurement or calculation 
ciated traits. Factor scores for each factor $Y_{j}$ were, generated for each $S_{0}$ plant or $S_{1}$ progeny of a population by a linear function of the values for traits $X_{i}$ through $X_{p}$, with each trait being weighted by its loading coefficient on that particular factor. The portion of variation of trait $X_{i}$ explained by the $\mathrm{m}$ common factors is termed the final communality and is estimated by the squared multiple correlation of $X_{i}$ with factor scores from the factors.

We correlated scores from each $S_{1}$ factor with scores from the $\mathrm{S}_{0}$ factor that was most similar to it within each composite. These correlations approximate standard unit heritability estimates (Frey \& Horner, 1957) and thus indicate the importance of genetic factors in determining each trait complex. We also correlated each $\mathrm{S}_{1}$ factor with all dissimilar $\mathrm{S}_{0}$ factors in order to determine if the different trait complexes were interrelated genetically. All correlations were based on $S_{0}$ plant- $S_{1}$ progeny pairs that had complete data in both generations. Numbers of pairs with complete data were $252,254,265$, and 285 pairs in the $\mathrm{D}_{2} \mathrm{C}, \mathrm{EC}, \mathrm{NELC}-\mathrm{I}$, and NELC-II populations, respectively.

\section{Results}

Structure of multitrait variation. Six multitrait factors were extracted from each of the four $S_{1}$ and three of the $S_{0}$ populations, and seven were identified from the NELC-II $S_{0}$ population. Within each population, factors were numbered (I, II, etc.) such that across populations, factors with similar loading coefficient vectors were numbered alike. Factor numbers were assigned according to descending order of magnitude of variation accounted for; e.g., Factor I accounted for 21 to $28 \%$ of the within-population variation after rotation, and Factors II to VII accounted for progressively smaller portions of the variances. In total, factor analysis accounted for 82 to $88 \%$ of the variation in each of the eight populations. Most traits had final communalities of 0.90 or larger in the eight populations. For Days to flowering $(\mathrm{DaFl})$, Tiller synchrony (TSyn), Height, Leaf width (LfWi), and 200 Seed weight $(200 \mathrm{SW})$, however, final communalities ranged from 0.48 to 0.87 , which shows that these traits exhibited variation that could not be fully explained by factor analysis.

Table 3. Loading coefficients $(\times 100)$ of plant traits with large loadings for Factor I or 'Biological Yield' axis of variation for four $\mathrm{S}_{0}$ and four $S_{1}$ populations of pearl millet

\begin{tabular}{|c|c|c|c|c|c|c|c|c|}
\hline \multirow[t]{3}{*}{ Trait } & \multicolumn{8}{|c|}{ Population } \\
\hline & \multicolumn{4}{|l|}{$\mathrm{S}_{0}$} & \multicolumn{4}{|l|}{$S_{1}$} \\
\hline & $\mathrm{D}_{2} \mathrm{C}$ & $\mathrm{EC}$ & NELC-I & NELC-II & $\mathrm{D}_{2} \mathrm{C}$ & $\mathrm{EC}$ & NELC-I & NELC-II \\
\hline Biomass & $94^{*}$ & $88^{*}$ & $91^{*}$ & $96^{*}$ & $93^{*}$ & $93^{*}$ & $81^{*}$ & $97^{*}$ \\
\hline GYd & $88^{*}$ & $86^{*}$ & $85^{*}$ & $88^{*}$ & $80^{*}$ & $55^{*}$ & 30 & $66^{*}$ \\
\hline GI & $83^{*}$ & $78^{*}$ & $85^{*}$ & $86^{*}$ & $90^{*}$ & $97^{*}$ & $93^{*}$ & $96^{*}$ \\
\hline SYd & $80^{*}$ & $72^{*}$ & $79 *$ & $84^{*}$ & $85^{*}$ & $98^{*}$ & $95^{*}$ & $98^{*}$ \\
\hline Height & $41^{*}$ & 28 & $39^{*}$ & $41^{*}$ & $67^{*}$ & $62 *$ & $62^{*}$ & $52^{*}$ \\
\hline Chaff & $83^{*}$ & $82 *$ & $81^{*}$ & $73^{*}$ & 11 & 0 & 7 & 9 \\
\hline $\mathrm{T} \#$ & $76^{*}$ & $77^{*}$ & $73^{*}$ & $53^{*}$ & 37 & 3 & -10 & 14 \\
\hline Th\% $\%$ & -2 & -2 & 3 & 17 & $58^{*}$ & $43^{*}$ & 24 & $52^{*}$ \\
\hline RR & 2 & -4 & -6 & -15 & $-49^{*}$ & $-76^{*}$ & $-89^{*}$ & $-54^{*}$ \\
\hline $\mathrm{HI}$ & 1 & -5 & -3 & -5 & 0 & $-44^{*}$ & $-70^{*}$ & -15 \\
\hline $\mathrm{DaFl}$ & -14 & -18 & -12 & 14 & 31 & $59^{*}$ & $49^{*}$ & $42^{*}$ \\
\hline $200 \mathrm{SW}$ & 9 & 5 & 11 & 20 & 27 & $40^{*}$ & $42^{*}$ & 18 \\
\hline Variance & 4.62 & 4.20 & 4.57 & 4.46 & 4.50 & 5.03 & 4.77 & 4.50 \\
\hline
\end{tabular}

* Value greater than the root mean square of all the values in the rotated factor pattern matrix of the respective populations. 
The orientation of a factor in the multidimensional space of all morphological and physiological traits of a population is shown by the magnitudes of the loading coefficients for the various plant traits on that factor. Factor I from the $\mathrm{D}_{2} \mathrm{CS}_{0}$ population, for example, was oriented toward plant mass, as indicated by the large loadings for Biomass, Straw yield (SYd), Grain yield (GYd), Growth index (GI), and Height (Table 3). A factor with similar large loading coefficients for Biomass, GYd, GI, SYd, and Height was identified in each of the other seven populations as well. This set of traits was considered to be a 'core group' because their relationships with Factor I in the eight populations transcended differences among composites and environments. A different 'core group' of traits occurred for each of the Factors I to VI (Tables 3 to 7). Each factor was interpreted as representing a particular biological aspect of plant growth or morphology according to the nature of the 'core group' of traits that defined the factor's orientation. For example, Factor I was interpreted to represent a 'Biological Yield' axis of variation because each 'core-group' trait described some aspect of plant mass. This axis of variation had been identified previously via multivariate analyses of pearl millet
(Bramel-Cox et al., 1987) and dry beans (Phaseolus vulgaris) (Denis \& Adams, 1978).

Factor II from four of the pearl millet populations (i.e., $\mathrm{S}_{0}$ of $\mathrm{D}_{2} \mathrm{C}, \mathrm{EC}$, and NELC-I and $\mathrm{S}_{1}$ of NELC-II) had large positive loading coefficients for Panicle surface area (PaSuAr) and the components of PaSuAr; i.e., Panicle length (PaLe) and Panicle girth (PaGi) (Table 4). Thus, Factor II represented a 'Panicle Size' axis of variation. Each of the other four populations had two factors that had large positive loading coefficients for $\mathrm{PaSuAr}$ and either PaLe or $\mathrm{PaGi}$, so these were labeled as the 'Panicle Length' and 'Panicle Circumference' axes, respectively. That separate factors represented panicle length and panicle circumference show that PaLe and PaGi exhibited greater independence in the latter four populations.

Reproductive ratio (RR) and Harvest index (HI), which measure the portions of total plant mass that are panicle and grain mass, respectively, had large coefficients on Factor III (Table 5). Factor III, therefore, was identified as a 'Dry-Matter Partitioning' axis. Negative loadings for SYd, GI, and Height in $\mathrm{S}_{0}$ populations and positive loadings for $G Y d$ in $S_{1}$ populations support this interpretation. The $S_{1}$ population of NELC-I differed from

Table 4. Loading coefficients $(\times 100)$ of plant traits with large loadings on Factor II or the 'Panicle Size' axis of variation from three $S_{0}$ and one $S_{1}$ population and on 'Panicle Length' and 'Panicle Circumference' axes of variation from the remaining four pearl millet populations

\begin{tabular}{|c|c|c|c|c|c|c|c|c|c|c|c|c|}
\hline \multirow[t]{2}{*}{ Trait } & \multicolumn{4}{|c|}{ Panicle Size } & \multicolumn{4}{|c|}{ Panicle Length } & \multicolumn{4}{|c|}{ Panicle Circumference } \\
\hline & $\begin{array}{l}\mathrm{D}_{2} \mathrm{C} \\
\mathrm{S}_{0}\end{array}$ & $\begin{array}{l}\mathrm{EC} \\
\mathrm{S}_{0}\end{array}$ & $\begin{array}{l}\text { NELC-I } \\
\mathrm{S}_{0} \\
\quad\end{array}$ & $\begin{array}{l}\text { NELC-II } \\
\mathrm{S}_{1} \\
\end{array}$ & $\begin{array}{l}\mathrm{D}_{2} \mathrm{C} \\
\mathrm{S}_{\mathrm{lr}}\end{array}$ & 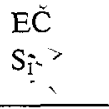 & $\begin{array}{l}\text { NELC-I } \\
\mathrm{S}_{1} \\
\end{array}$ & $\begin{array}{l}\text { NELC-II } \\
\mathrm{S}_{0} \\
\end{array}$ & $\begin{array}{l}\mathrm{D}_{2} \mathrm{C} \\
\mathrm{S}_{1} ! \\
\vdots\end{array}$ & $\begin{array}{l}\mathrm{EC} \\
\mathrm{S}_{1}\end{array}$ & $\begin{array}{l}\text { NELC-I } \\
S_{-1}\end{array}$ & $\begin{array}{l}\text { NELC-II } \\
\mathrm{S}_{0} .\end{array}$ \\
\hline PaLe & $89^{*}$ & $75^{*}$ & $81^{*}$ & $81^{*}$ & $94 *$ & $91^{*}$ & $94^{*}$ & $96^{*}$ & -19 & -1 & -5 & -14 \\
\hline $\mathrm{PaGi}$ & $58^{*}$ & $79^{*}$ & $51^{*}$ & $60^{*}$ & 13 & 26 & 14 & 7 & $93 *$ & $80^{*}$ & $88^{*}$ & $92 *$ \\
\hline PaSuAr & $96^{*}$ & $94^{*}$ & $90^{*}$ & $96^{*}$ & $93^{*}$ & $88^{*}$ & $88^{*}$ & $86^{*}$ & 24 & $42^{*}$ & $42^{*}$ & $45^{*}$ \\
\hline $\mathrm{T} \#$ & -33 & -33 & $-43^{*}$ & -37 & $-65^{*}$ & -26 & $-43^{*}$ & -17 & -25 & $-54^{*}$ & -36 & $-43^{*}$ \\
\hline $\mathrm{S} \# / \mathrm{Pa}$ & $72^{* *}$ & $68^{*}$ & $72 *$ & 20 & $52 *$ & 26 & 27 & $36^{*}$ & 24 & 23 & 22 & 26 \\
\hline Height & 37 & $43^{*}$ & $44^{*}$ & 32 & 14 & 36 & 30 & $47^{*}$ & -13 & 14 & 0 & 15 \\
\hline $\mathrm{DaFl}$ & 35 & $39 *$ & $46^{*}$ & 11 & 4 & -2 & 1 & -6 & 35 & 17 & 15 & $36^{*}$ \\
\hline LfWi & $60^{*}$ & $58 *$ & $57^{*}$ & 14 & - & 0 & 6 & 20 & - & $77^{*}$ & $61^{*}$ & 33 \\
\hline $\mathrm{CoSc}$ & -3 & -13 & -1 & $-53^{*}$ & -15 & $-58 *$ & -35 & -17 & -4 & -1 & -22 & -9 \\
\hline PPGYd & $79^{*}$ & $78^{*}$ & $79^{*}$ & - & - & - & - & $46^{*}$ & - & . - & - & $52 *$ \\
\hline Variance & 4.17 & 4.32 & 4.13 & 2.70 & 2.55 & 2.33 & 2.27 & 2.41 & 1.50 & 1.88 & 1.63 & 2.07 \\
\hline
\end{tabular}

\footnotetext{
* Value greater than the root mean square of all the values in the rotated factor pattern matrix of the respective populations.
} 
others in that the loading of GYd on Factor III was larger than that for $\mathrm{HI}$ and the loading for $\mathrm{RR}$ was not significant.

Seed number per panicle (S\#/Pa) and $200 \mathrm{SW}$ had large loading coefficients with opposite signs on Factor IV (Table 6), which suggests that Factor IV represents cómpensation between seed number and seed size. The orientation of Factor IV toward large S\#/Pa and small $200 \mathrm{SW}$ or vice versa probably is a function of whether $200 \mathrm{SW}$ or the group of

Table 5. Loading coefficients $(\times 100)$ of plant traits with large loadings on Factor III or 'Dry-Matter Partitioning' axis of variation for four $S_{0}$ and four $S_{1}$ populations

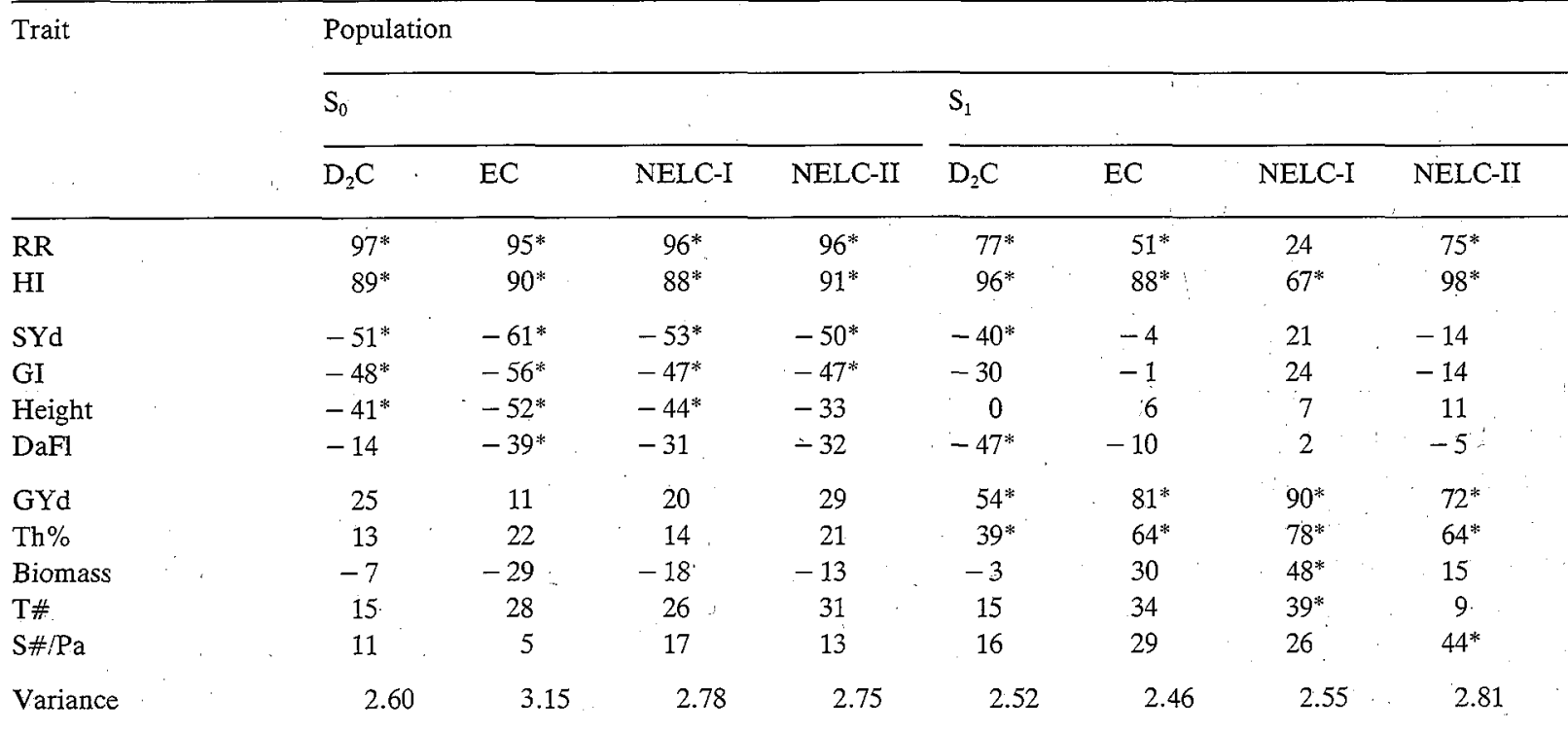

* Value greater than the root mean square of all the values in the rotated factor pattern matrix of the respective populations.

Table 6. Loading coefficients $(\times 100)$ of plant traits with large loadings on Factor IV or 'Seed Parameters' axis from four $\mathrm{S}_{0}$ and four $\mathrm{S}_{1}$ millet populations

\begin{tabular}{|c|c|c|c|c|c|c|c|c|}
\hline \multirow[t]{3}{*}{ Trait } & \multicolumn{8}{|c|}{ Population } \\
\hline & \multicolumn{4}{|l|}{$\mathrm{S}_{0}$} & \multicolumn{3}{|l|}{$\mathrm{S}_{1}$} & \multirow{2}{*}{ NELC-II } \\
\hline & $\mathrm{D}_{2} \mathrm{C}$ & $\mathrm{EC}$ & NELC-I & NELC-II & $\mathrm{D}_{2} \mathrm{C}$ & $\mathrm{EC}$ & NELC-I & \\
\hline $\mathrm{S} / \mathrm{Pa}$ & $52 *$ & $-50^{*}$ & $37^{*}$ & $78^{*}$ & $72^{*}$ & $80^{*}$ & $83^{*}$ & $-63^{*}$ \\
\hline $200 \mathrm{SW}$ & $-76^{*}$ & $83^{*}$ & $-53^{*}$ & $+64^{*}$ & $-66^{*}$ & $-62^{*}$ & $-44^{*}$ & $88^{*}$ \\
\hline CoSc & $70^{*}$ & $-50^{*}$ & $86^{*}$ & $85^{*}$ & $76^{*}$ & $59^{*}$ & $69^{*}$ & -28 \\
\hline $\mathrm{DaFl}$ & $49^{*}$ & -18 & 16 & $61^{*}$ & $60^{*}$ & $53 *$ & $68^{*}$ & $-54^{*}$ \\
\hline LfWi & -9 & -35 & 16. & $35^{*}$ & - & 24 & 27 & 8 \\
\hline PPGYd & 25 & -19 & 14 & $46^{*}$ & - & - & - & - \\
\hline $\mathrm{PaGi}$ & -19 & 2 & $-49^{*}$ & -3 & -5 & -20 & -15 & 38 \\
\hline $\mathrm{T} \#$ & -16 & 7 & -8 & -32 & $-38^{*}$ & $-35^{*}$ & $-55^{*}$ & 10 \\
\hline Height & 8 & 5 & 2 & 24 & -16 & 30 & $38 *$ & -35 \\
\hline$\overline{\mathbf{x}}$ Variance & 1.78 & 1.45 & 1.61 & 2.70 & 2.24 & 2.03 & 2.49 & 1.88 \\
\hline
\end{tabular}

* Value greater than the root mean square of all the values in the rotated factor pattern matrix of the respective populations. 
traits $[\mathrm{S} \# / \mathrm{Pa}$, Compactness score $(\mathrm{CoSc})$, and $\mathrm{DaFl}$ ] had the larger amount of variation accounted for by this factor. Our interpretation of Factor IV supports the suggestion of Grafius \& Thomas (1971) that S\#/Pa and 200 SW are members of a single developmental sequence in which the magnitude of an initial component inversely affects the size of a subsequent component.

Factor $\mathrm{V}$ had large loadings with opposite signs for Threshing percent (Th\%) and Chaff (Table 7). Because $\mathrm{Th} \%$ measures that proportion of panicle mass that is grain and Chaff is the panicle mass that is not grain, this axis was interpreted to represent 'Panicle Partitioning'. S\#/Pa and $200 \mathrm{SW}$ had small loading coefficients on this axis, which shows that these traits, taken individually, were independent from the grain to chaff ratio of the panicle. The reversal of signs and magnitudes of loadings of Th $\%$ and Chaff between $S_{0}$ and $S_{1}$ populations may have resulted from the different magnitudes of variation for these traits that were associated with Factor I; i.e., Chaff and Th\% had large loadings for Factor $\mathrm{I}$ in $\mathrm{S}_{0}$ and $\mathrm{S}_{1}$ populations, respectively (Table 3).

Environmental influence on trait associations. When grown in field experiments, an $\mathrm{S}_{0}$ plant occupied seven times more land area than did an $S_{1}$ plant ( 0.56 vs. $\left.0.08 \mathrm{~m}^{2}\right)$, which resulted in more tillers per $\mathrm{S}_{0}$ plant (Table 1). The large loading coefficients for Tiller number ( $\mathrm{T} \#$ ) on the 'Biological Yield' Factors of the four $S_{0}$ populations (Table 3) reflect the importance of tillering to the mass of a spaced plant. In the $S_{1}$ populations, $T \#$ had no significant loadings on 'Biological Yield' factors, whereas positive loadings for $\mathrm{DaFl}$ did occur. However, loading coefficients for GI were even larger than those for $\mathrm{DaFl}$, which shows that growth rate was more important than duration of growth in determining Biomass of $S_{1}$ progenies.

Another major difference between $S_{0}$ spaced plants and $S_{1}$ progenies involved the loadings of Th $\%$ and RR on Factor I (Table 3). Positive Th\% and negative RR loadings for $S_{1}$ populations show that progenies with high Biomass had well filled panicles but had less complete remobilization of dry matter, whereas progenies with low Biomass effectively translocated dry matter to the panicle but had panicles poorly filled with grain; conditions typical of 'sink' and 'source' limitations, respectively. In contrast, $\mathrm{S}_{0}$ populations had small loadings for Th\% and RR on Factor I. This shows that, among spaced plants, Biomass and partitioning were independent and suggests that both the 'source' and 'sink' parameters increased concomitantly.

Table 7. Plant traits with large loading coefficients $(\times 100)$ on Factor $V$ or 'Panicle Partitioning' axis from four $S_{0}$ and four $S_{1}$ millet populations

\begin{tabular}{|c|c|c|c|c|c|c|c|c|}
\hline \multirow[t]{3}{*}{ Trait } & \multicolumn{8}{|c|}{ Population } \\
\hline & \multicolumn{4}{|l|}{$\mathrm{S}_{0}$} & \multicolumn{4}{|l|}{$S_{1}$} \\
\hline & $\mathrm{D}_{2} \mathrm{C}$ & $\mathrm{EC}$ & NELC-I & NELC-II & $\mathrm{D}_{2} \mathrm{C}$ & $\mathrm{EC}$ & NELC-I & NELC-II \\
\hline Th\% & $93^{*}$ & $88^{*}$ & $92^{*}$ & $91^{*}$ & $-68^{*}$ & $-60^{*}$ & $-54^{*}$ & $-51^{*}$ \\
\hline Chaff & $-40^{*}$ & $-40^{*}$ & $-43^{*}$ & $-61^{*}$ & $96^{*}$ & $95^{*}$ & $95^{*}$ & $91^{*}$ \\
\hline $\mathrm{HI}$ & $41^{*}$ & $39^{*}$ & $41^{*}$ & 35 & -21 & -9 & -9 & -1 \\
\hline PPGYd & $40^{*}$ & $53^{*}$ & $49^{*}$ & $37^{*}$ & - & - & - & - \\
\hline $\mathrm{CoSc}$ & 34 & $60^{*}$ & 27 & 10 & 7 & -8 & 5 & -20 \\
\hline $\mathrm{S \# /Pa}$ & 26 & $44^{*}$ & 32 & 13 & -9 & -11 & 4 & -26 \\
\hline $\mathrm{T} \#$ & -7 & -16 & -13 & -7 & 19 & $51^{*}$ & 29 & $59^{*}$ \\
\hline Variance & 1.74 & 2.23 & 1.99 & 1.75 & 1.68 & 1.85 & 1.54 & 1.97 \\
\hline
\end{tabular}

\footnotetext{
*Value greater than the root mean square of all the values in the rotated factor pattern matrix of the respective populations.
} 
Large GYd loadings on Factor I for both spacedplant and normal-density row environments show that the association between GYd and biological yield is environmentably stable (Table 3). The association between GYd and HI, however, was limited to the $S_{1}$ progeny-row environment as indicat- ed by the larger positive GYd loadings on Factor III of $S_{1}$ relative to $S_{0}$ populations (Table 5).

That greater compensation occurred between $T \#$ and $S \# / P$ a for $S_{1}$ progenies than for $S_{0}$ spaced plants was shown by the loading coefficients for T\# on the respective $S_{1}$ and $S_{0}$ 'Seed Parameter'

Table 8. Intergeneration correlations among factors extracted from $\mathrm{S}_{0}$ and $\mathrm{S}_{1}$ populations in each of three pearl millet composites

\begin{tabular}{|c|c|c|c|c|c|c|c|}
\hline \multirow{2}{*}{$\begin{array}{l}\text { Factors from } \mathrm{S}_{1} \\
\text { populations }\end{array}$} & \multirow[t]{2}{*}{ Composite } & \multicolumn{6}{|c|}{ Factors from $S_{0}$ populations } \\
\hline & & $\begin{array}{l}\text { I } \\
\text { 'Biological } \\
\text { yield' }\end{array}$ & $\begin{array}{l}\text { II } \\
\text { 'Panicle size'a }\end{array}$ & $\begin{array}{l}\text { III } \\
\text { 'Dry matter } \\
\text { partitioning' }\end{array}$ & $\begin{array}{l}\text { IV } \\
\text { 'Seed } \\
\text { parameters'b }\end{array}$ & $\begin{array}{l}\mathrm{V} \\
\text { 'Panicle } \\
\text { partitioning' }\end{array}$ & $\begin{array}{l}\text { VI } \\
\text { 'Tiller } \\
\text { synchrony' }\end{array}$ \\
\hline \multicolumn{8}{|l|}{$I$} \\
\hline 'Biological yield' & $\begin{array}{l}\mathrm{D}_{2} \mathrm{C} \\
\text { EC } \\
\text { NELC-I } \\
\text { NELC-II }\end{array}$ & $\begin{array}{l}0.24^{* * *} \\
0.23^{* *} \\
0.19^{* * *} \\
0.48^{* * *}\end{array}$ & $\begin{array}{l}0.09 \\
0.15^{*} \\
0.19^{* *} \\
0.17^{* *} 0.26^{* *}\end{array}$ & $\begin{array}{l}-0.26^{* *} \\
-0.53^{* *} \\
-0.38^{* *} \\
-0.33^{* *}\end{array}$ & $\begin{array}{c}-0.13^{*} \\
-0.13^{*} \\
-0.04 \\
0.35^{* *}\end{array}$ & $\begin{array}{l}0.07 \\
0.10 \\
0.24^{* *} \\
0.17^{* *}\end{array}$ & $\begin{array}{l}0.08 \\
0.12 \\
0.07 \\
0.05\end{array}$ \\
\hline II & & & & & & & \\
\hline 'Panicle length' & $\begin{array}{l}\mathrm{D}_{2} \mathrm{C} \\
\mathrm{EC} \\
\text { NELC-I }\end{array}$ & $\begin{array}{l}-0.03 \\
-0.05 \\
-0.06\end{array}$ & $\begin{array}{l}0.48^{* *} \\
0.41^{* *} \\
0.42^{* *}\end{array}$ & $\begin{array}{l}0.04 \\
0.00 \\
0.07\end{array}$ & $\begin{array}{l}-0.08 \\
-0.24^{* *} \\
-0.28^{* *}\end{array}$ & $\begin{array}{l}-0.09 \\
-0.03 \\
-0.04\end{array}$ & $\begin{array}{c}-0.17^{* *} \\
0.11 \\
-0.07\end{array}$ \\
\hline $\begin{array}{l}\text { 'Panicle } \\
\text { circumference' }\end{array}$ & $\begin{array}{l}\mathrm{D}_{2} \mathrm{C} \\
\mathrm{EC} \\
\text { NELC-I }\end{array}$ & $\begin{array}{l}0.09 \\
0.01 \\
0.05\end{array}$ & $\begin{array}{l}0.33^{* *} \\
0.34^{* *} \\
0.39^{* * *}\end{array}$ & $\begin{array}{c}0.03 \\
-0.16^{* *} \\
0.00\end{array}$ & $\begin{array}{l}-0.16^{* *} \\
-0.07 \\
-0.44^{* *}\end{array}$ & $\begin{array}{c}0.03 \\
-0.13 * \\
-0.01\end{array}$ & $\begin{array}{r}0.26^{* *} \\
-0.23^{* *} \\
-0.11\end{array}$ \\
\hline 'Panicle size' & NELC-II & $0.14^{*}$ & $0.67^{* *} 0.50 * *$ & 0.00 & 0.11 & $0.13^{*}$ & -0.07 \\
\hline III & & & & & & & \\
\hline $\begin{array}{l}\text { 'Dry matter } \\
\text { partitioning' }\end{array}$ & $\begin{array}{l}\mathrm{D}_{2} \mathrm{C} \\
\mathrm{EC} \\
\text { NELC-I } \\
\text { NELC-II }\end{array}$ & $\begin{array}{l}0.06 \\
0.09 \\
0.21^{* *} \\
0.14^{*}\end{array}$ & $\begin{array}{l}0.06 \\
0.15^{*} \\
-0.02 \\
0.15^{*} 0.04\end{array}$ & $\begin{array}{c}-0.05 \\
0.04 \\
0.05 \\
0.23^{* *}\end{array}$ & $\begin{array}{c}-0.11 \\
-0.15^{*} \\
0.06 \\
0.21^{* *}\end{array}$ & $\begin{array}{l}0.19^{* *} \\
0.28^{* *} \\
0.09 \\
0.21^{* *}\end{array}$ & $\begin{array}{r}0.08 \\
-0.04 \\
0.02 \\
0.07\end{array}$ \\
\hline rV & & & & & & & \\
\hline 'Seed parameters' & $\begin{array}{l}\mathrm{D}_{2} \mathrm{C} \\
\mathrm{EC} \\
\text { NELC-I } \\
\text { NELC-II }\end{array}$ & $\begin{array}{l}0.03 \\
0.13^{*} \\
0.10 \\
0.13^{*}\end{array}$ & $\begin{array}{l}0.18^{* *} \\
0.25^{* *} \\
0.44^{* *} \\
0.14^{*} 0.06\end{array}$ & $\begin{array}{c}0.19^{* *} \\
-0.10 \\
0.05 \\
0.01\end{array}$ & $\begin{array}{l}0.34^{* *} \\
0.35^{* *} \\
0.43^{* *} \\
0.65^{* *}\end{array}$ & $\begin{array}{l}0.04 \\
0.28^{* *} \\
0.29^{* *} \\
-0.02\end{array}$ & $\begin{array}{l}0.00 \\
0.18^{* *} \\
0.14^{*} \\
0.32^{* *}\end{array}$ \\
\hline $\mathrm{V}$ & & & & & & & \\
\hline 'Panicle partitioning'c & $\begin{array}{l}\mathrm{D}_{2} \mathrm{C} \\
\mathrm{EC} \\
\text { NELC-I } \\
\text { NELC-II }\end{array}$ & $\begin{array}{c}0.02 \\
-0.12^{*} \\
-0.03 \\
0.18^{* *}\end{array}$ & $\begin{array}{l}-0.07 \\
-0.09 \\
-0.09 \\
0.110 .15^{*}\end{array}$ & $\begin{array}{l}-0.16^{*} \\
-0.22^{* *} \\
-0.18^{* *} \\
-0.25^{* *}\end{array}$ & $\begin{array}{l}-0.13^{*} \\
-0.21^{* *} \\
-0.08 \\
0.40^{* *}\end{array}$ & $\begin{array}{l}0.22^{* *} \\
0.10 \\
0.11 \\
0.22^{* *}\end{array}$ & $\begin{array}{c}0.10 \\
-0.17^{* *} \\
-0.09 \\
0.00\end{array}$ \\
\hline $\begin{array}{l}\text { VII } \\
\text { 'Leaf width' }\end{array}$ & NELC-II & $0.19^{* *}$ & $0.23 * * 0.45^{* *}$ & $-0.23^{* *}$ & $0.63^{* *}$ & -0.06 & $-0.26^{* *}$ \\
\hline
\end{tabular}

a NELC-II $\mathrm{S}_{0}$ population with two factors identified as 'Panicle length' (left) and 'Panicle circumference' (right) axes.

${ }^{\mathrm{b}}$ Signs of $E C \mathrm{~S}_{0}$ and NELC-II $\mathrm{S}_{1}$ Factor IV scores reversed so that Factor IV scores of all populations reflect positive S\#/Pa and negative 200SW loadings.

${ }^{c}$ Factor V scores of $S_{1}$ populations were reversed in sign so that both $S_{0}$ and $S_{1}$ Factor V scores reflect positive Th\%.

*,** Denote significance at the 0.05 and 0.01 levels, respectively. 
factors (Table 6). This conclusion is supported by the fact that the negative correlations between $\mathrm{T} \#$ and $\mathrm{S \# /Pa}$ were larger for $\mathrm{S}_{1}$ populations $(\mathrm{r}=$ $-0.44^{* *}$ to $\left.-0.61^{* *}\right)$ than for $\mathrm{S}_{0}$ populations $(\mathrm{r}=$ $-0.21^{* *}$ to $\left.-0.23^{* *}\right)$.

Genetic determination of trait associations. Trait relationships identified via factor analysis within each population were phenotypic. That these relationships had a genetic component is shown by the significant correlations of $S_{1}$ progeny factor scores with scores for the same factor from parental $S_{0}$ plants (diagonal of Table 8). Heritable variation for the 'Biological Yield', 'Panicle Size', and 'Seed Parameter' axes was exhibited for all composites. That correlations of $S_{1}$ with $S_{0}$ 'Dry-Matter Partitioning' and 'Panicle Partitioning' Factors were significant only occasionally indicates low heritabilities or changes in orientation for these factors across generations.

\section{Discussion}

The factor analysis algorithm identified factors that were independent from one another, except for small correlations induced by factor rotation, in the eight pearl millet populations studied. Significant relationships among different factors were found, however, when $S_{1}$ factor-scores were correlated with scores from dissimilar $S_{0}$ factors (off-diagonal correlations of Table 8). For example, the correlations of $S_{1}$ 'Biological Yield' factor scores with $S_{0}$ 'Panicle Size' and 'Dry-Matter Partitioning' factor scores usually were significant. Such interrelationships among different factors from one generation to the next suggest the existence of pleiotropic genes that govern an underlying developmental pattern that influences several characteristics.

The occurrence of genetically induced relationships among different pearl millet traits or trait complexes would have two possible consequences on the selection methodology used to improve this crop. First, some type of restriction upon selection would be required when selection for one trait could cause an undesirable correlated response of another trait. For instance, the negative associ- ation between $\mathrm{HI}$ and Biomass, represented by correlations of $S_{1}$ Factor I with $S_{0}$ Factor III (Table 8), would require that selection for increased $\mathrm{HI}$ be restricted so as to prevent unacceptable decreases of Biomass. Second, indirect selection may be used to exploit favorable trait associations. One such association is between the $S_{0}$ 'Panicle Partitioning' and the $\mathrm{S}_{1}$ 'Dry-Matter Partitioning' axes (Table 8), which shows that $\mathrm{Th} \%$, an easily and commonly measured trait, could be used to indirectly select for $\mathrm{HI}$, a trait that is difficult to measure.

The identification of factors with similar loadings of traits for all three pearl millet composites (Tables 3 to 7) could be the result of similarity across composites of (a) genetically induced trait correlations, (b) environmental correlations among traits, or (c) correlations of measurement errors due to calculating several traits from a single measure; e.g., Biomass, GI, HI, and RR all use SYd in their computations (Table 2). To assess whether trait relationships identified via factor analysis were due to measurement error correlations arising from the computational relationships among traits, we reanalyzed each population by using only traits that were measured independently ( 12 in $S_{0}$ populations and 10 in all $S_{1}$ populations except $D_{2} C$ which had 9).

Three or four factors were extracted for each population by utilizing a correlation matrix of these independently measured traits. A factor that represented 'Biological Yield' was identified in 'each population with large loadings for $\mathrm{T} \#, \mathrm{SYd}$, and Panicle yield (PYd) in $S_{0}$ and GYd, SYd, Height, and $\mathrm{DaFl}$ in $\mathrm{S}_{1}$ populations. A factor representing 'Panicle Length' occurred in five populations, and one representing 'Panicle Length and Circumference' occurred in two others. Large loadings of opposite signs occurred for $200 \mathrm{SW}$ and CoSc in another factor for all $S_{0}$ and three $S_{1}$ populations. The only result that differed from the factor analyses that utilized all traits was the association between maturity and biomass for spaced plants, indicated by large loadings for $\mathrm{DaFl}$, Height, and SYd on one factor in the EC and NELC-I S $\mathrm{S}_{0}$ populations. The similarity of factors identified from directly measured traits with those from all traits shows that the trait relationships that we identified 
initially were not caused by correlations due to measurement errors. That trait complexes were similar in all composites shows that plant breeders could use similar selection procedures for improving pearl millet composites of diverse phenotypes.

Factor analysis has been used to identify a limited set of plant traits that best predict the yield potential of spring wheat (Triticum aestivum) genotypes (Walton, 1972). Because our pearl millet composites were undergoing recurrent selection to increase GYd, we decided to assess the value of each $\mathrm{S}_{0}$ factor as a criterion for GYd selection by regressing $S_{1} G Y d$ on scores from each $S_{0}$ factor (Table 9). Positive and highly significant linear regression coefficients were obtained when regressing upon the $\mathrm{S}_{0}$ 'Biological Yield', 'Panicle Size', and 'Panicle Partitioning' factors, indicating that these trait complexes corresponded favorable with yield potential in the subsequent generation. $S_{0}$ plants with 'Biological Yield' factor scores one standard deviation above the $S_{0}$ population mean, for example, were predicted to produce $S_{1}$ progenies with GYd 113 to $172 \mathrm{~kg} \mathrm{ha}^{-1}$ above that of the $\mathrm{S}_{1}$ population mean, noting that the mean and variance of the factor scores are 0.0 and 1.0 , respectively. Negative coefficients were obtained when regression upon the $\mathrm{D}_{2} \mathrm{C}$ and $\mathrm{EC}$ 'Dry Matter Parti- tioning' factor, which shows this to be an anti-yield factor.

To evaluate the unique contribution of each $\mathrm{S}_{0}$ factor to predicting the yield of $S_{1}$ progenies, multiple regressions of $S_{1} G Y d$ on scores from all six or seven $S_{0}$ factors within each composite were conducted (Table 9). The $S_{0}$ 'Biological Yield' and 'Panicle Partitioning' factors had consistently large positive partial regression coefficients whereas those for the 'Seed Parameters' factor differed among the composites. These partial regression coefficients suggest that the most effective selection criteria for increasing GYd would be Biomass, $\mathrm{Th} \%$, and $200 \mathrm{SW}$ for the $\mathrm{EC}$ and $\mathrm{D}_{2} \mathrm{C}$ composites and Biomass, Th\%, and $\mathrm{S} / \mathrm{Pa}$ for the NELC pearl millet composite.

\section{References}

Bramel-Cox, P.J., D.J. Andrews \& K.J. Frey, 1987. Trait associations in introgressed populations of pearl millet. Plant Breed. 98: 17-24.

Bramel-Cox, P.J., D.J. Andrews, F.R. Bidinger \& K.J. Frey, 1984. A rapid method of evaluating growth rate in pearl millet and its weedy and wild relatives. Crop Sci. 24: 1187-1191.

Brunken, J., J.M.J. De Wet \& J.R. Harlan, 1977. The morphology and domestication of pearl millet. Econ. Bot. 31: 163174.

Table 9. Linear regression coefficients for $\mathrm{S}_{1}$ grain yield $\left(\mathrm{kg} \mathrm{ha}^{-1}\right)$ upon scores for individual $\mathrm{S}_{0}$ rotated factors and partial regression coefficients from multiple linear regressions of $S_{1}$ grain yield on scores from all $S_{0}$ factors

Composite

Factors from $\mathrm{S}_{0}$ populations

\begin{tabular}{lllll}
\hline I II & III & IV & V & VI \\
'Biological yield' 'Panicle size' & 'Dry matter & 'Seed & 'Panicle & 'Tiller \\
& partitioning' & parameters' & partitioning' & synchrony'
\end{tabular}

Linear regression coefficients

$\mathrm{D}_{2} \mathrm{C}$
$\mathrm{EC}$
$\mathrm{NELC}-\mathrm{I}$
NELC-II
Partial regression coefficients

N


Burton, G.W., 1959. Breeding methods for pearl millet (Pennisetum glaucum) indicated by genetic variance component studies. Agron. J. 51: 479-481.

Denis, J.C. \& M.W. Adams, 1978. A factor analysis of plant variables related to yield in dry beans. I. Morphological traits. Crop Sci. 18: 74-78.

Frey, K.J. \& T. Horner, 1957. Heritability in standard units. Agronomy J. 49: 59-62.

Grafius, J.E. \& R.L. Thomas, 1971. The case of indirect genetic control of sequential traits and the strategy of deployment of environmental resources by the plant. Heredity 26: 433-442.
Karson, M.J., 1982. Multivariate Statistical Methods. Iowa State Univ. Press, Ames, Iowa, USA.

Khadr, F.H., 1977. Recurrent selection in pearl millet (Pennisetum typhoides) in northern Nigeria. Plant Breed. 79: 145-153.

Marchais, L. \& S. Tostain, 1985. Genetic divergence between wild and cultivated pearl millets (Pennisetum typhoides). II. Characters of domestication. Plant Breed. 95: 245-261.

Stebbins, G.L., 1950. Variation and evolution in plants. Columbia Univ. Press. New York, New York, USA:

Walton, P.D., 1972. Factor analysis of yield in spring wheat (Triticum aestivum L.). Crop Sci. 12: 731-733. 